\title{
PENERAPAN PENDEKATAN CONCRETE-PICTORIAL- ABSTRACT TERHADAP KEMAMPUAN PEMAHAMAN KONSEP MATEMATIS PADA MATA PELAJARAN MATEMATIKA KELAS V SD
}

\author{
Firda Maulani', Indhira Asih V. Y2, Trian Pamungkas Alamsyah ${ }^{3}$ \\ IUniversitas Sultan Ageng Tirtayasa \\ 2Universitas Sultan Ageng Tirtayasa \\ 3Universitas Sultan Ageng Tirtayasa \\ firdamaulani09@gmail.com
}

\begin{abstract}
One problem faced by students is the lack of understanding of students' mathematical concepts. A concrete-Pictorial-Abstract Approach is a learning approach that can be applied to practice the students' mathematical concept understanding abilities. This study aimed to determine whether the ability to understand mathematical concepts that use the Concrete-Pictorial-Abstract approach is better than the scientific approach in Mathematics $\vee$ grade at SDN Simpang Tiga. This study uses a quasi-experimental method in the form of Pretest-Posttest Control Group Design. The population used in this study were all Simpang Tiga Elementary School students enrolled in the 2019/2020 school year. The sampling technique used in this study is purposive sampling, namely the $V_{B}$ class as the experimental class and $V_{A}$ as the control class. The instrument used in the study was a matter of describing the ability to understand mathematical concepts-the data analysis using a t-test. The results showed that $t_{\text {count }}>t_{\text {table }}$, so $\mathrm{H}_{0}$ was rejected. Thus it can be concluded that the ability to understand mathematical concepts that use the Concrete-Pictorial-Abstract approach is better than the Scientific method in Mathematics class $V$ at SDN Simpang Tiga.
\end{abstract}

Keywords: Concrete-Pictorial-Abstract, the ability to understand mathematical concepts, mathematics

\begin{abstract}
ABSTRAK Salah satu masalah yang dihadapi siswa yaitu rendahnya pemahaman konsep matematis siswa. Pendekatan Concrete-Pictorial-Abstract merupakan pendekatan pembelajaran yang dapat diterapkan untuk melatih kemampuan pemahaman konsep matematis siswa. Tujuan penelitian ini ialah untuk mengetahui apakah kemampuan pemahaman konsep matematis yang menggunakan pendekatan Concrete-PictorialAbstract lebih baik daripada pendekatan Saintifik pada mata pelajaran Matematika kelas $V$ SD di SDN Simpang Tiga. Penelitian ini menggunakan metode kuasi eksperimen dengan bentuk design Pretest-Posttest Control Group Design. Populasi yang digunakan dalam penelitian ini adalah seluruh siswa SDN Simpang Tiga yang terdaftar pada tahun ajaran $2019 / 2020$. Teknik yang digunakan untuk pengambilan sampel pada penelitian ini ialah sampling purposive yaitu kelas VB sebagai kelas eksperimen dan VA sebagai kelas kontrol. Instrumen yang digunakan pada penelitian adalah soal uraian kemampuan pemahaman konsep matematis. Analisis data menggunakan uji-t. hasil penelitian menunjukkan bahwa $t_{\text {hitung }}>t_{\text {tabel }}$ sehingga $H_{0}$ ditolak. Dengan demikian dapat disimpulkan bahwa Kemampuan pemahaman konsep matematis yang menggunakan pendekatan Concrete-PictorialAbstract lebih baik daripada pendekatan Saintifik pada mata pelajaran Matematika kelas $V$ di SDN Simpang Tiga.
\end{abstract}


Kata-kata kunci: Concrete-Pictorial-Abstract, kemampuan pemahaman konsep matematis, matematika

\section{PENDAHULUAN}

Pendidikan merupakan suatu wadah terciptanya kegiatan pembelajaran yang mencakup aspek pengetahuan, sikap serta keterampilan guna mengembangkan bakat dan potensi siswa. Pendidikan diperoleh salah satunya yaitu dari sekolah, sekolah merupakan pendidikan formal di mana siswa dapat belajar dan berinteraksi dengan orang lain serta tempat siswa untuk mengembangkan keterampilan yang dimilikinya. Sekolah merupakan hal yang penting bagi setiap siswa guna menjadi manusia yang terampil dan berpotensi. Belajar merupakan usaha seseorang untuk memperoleh suatu informasi dari yang tidak tahu menjadi tahu sehingga bertambahnya pengetahuan seseorang. Seperti yang dikemukakan oleh Gagne (Taufik, 2013: 78) bahwa belajar dapat didefinisikan sebagai suatu proses dimana suatu organisasi berubah perilakunya sebagai akibat pengalaman.

Keberhasilan suatu pendidikan dapat dilihat dari keberhasilan Proses Pembelajaran. Guru sebagai perancang kegiatan pembelajaran berperan penting dalam proses pembelajaran. Guru harus mengorganisir kegiatan pembelajaran agar mencapai suatu tujuan pembelajaran. Kemampuan seorang guru sangatlah berpengaruh terdahap pencapaian tujuan pembelajaran. Semakin baik kemampuan yang dimiliki guru, maka semakin besar pula peluang keberhasilan pembelajaran.

Keberhasilan suatu pembelajaran dipengaruhi oleh kegiatan pembelajaran yang dilakukan, kegiatan pembelajaran harus dirancang salah satunya dengan pemilihan pendekatan pembelajaran yang sesuai digunakan dalam proses pembelajaran tersebut. Pendekatan pembelajaran inilah yang dijadikan guru sebagai cara dalam melaksanakan proses pembelajaran. Seperti yang diungkapkan oleh Anitah, dkk (2014: 1.23) bahwa pendekatan pembelajaran adalah cara memandang terhadap pembelajaran. Dengan pendekatan pembelajaran, proses pembelajaran dapat menjadi efektif dan efisien termasuk pada pembelajaran matematika.

Pembelajaran matematika di sekolah dasar merupakan hal yang mengajarkan siswa untuk menyelesaikan suatu persoalan dengan menggunakan angka-angka serta simbol-simbol seperti yang diungkapkan oleh Amir (2014:74) matematika merupakan ide-ide abstrak yang diberi simbol-simbol, maka konsep matematika harus dipahami terlebih dahulu sebelum memanipulasi simbol-simbol itu. Sehingga matematika seringkali dianggap sulit khususnya pada siswa sekolah dasar, padahal matematika merupakan mata pelajaran yang penting dikuasi oleh siswa agar dapat mengembangkan pola pikirnya yang berguna bagi kehidupannya. Seperti yang dikemukakan Russefendi (Novitasari, 2016: 8) bahwa terdapat banyak anak-anak setelah belajar matematika bagian bagian yang sederhana, banyak yang tidak dipahaminya, dan banyak konsep yang dipahami secara keliru. Padahal konsep adalah suatu gagasan atau sekelompok fakta atau keterangan yang memiliki makna (Wulandari \& Sutriyono,2018:76). 
Konsep-konsep yang dipahami secara keliru ini menandakan bahwa rendahnya pemahaman konsep matematis siswa yang ditandai dengan kurangnya kemampuan siswa dalam menyatakan ulang sebuah konsep yang telah dipelajarinya dan kurangnya pemahaman siswa dalam menyelesaikan soal cerita sehingga ketika ditulis dalam bentuk kalimat matematika siswa cenderung kesulitan dalam menyelesaikan persoalan. Kesulitan dalam menyelesaikan persoalan matematika ini diakibatkan karena siswa cenderung menghafal dibandingkan memahami konsep yang sebenarnya.

Tujuan kurikulum pembelajaran matematika yang tercantum dalam Permendiknas Nomor 22 tahun 2006 (Yuliyanto, Putri, Rahayu, 2019: 75-76) salah satunya adalah "Memahami konsep matematika, menjelaskan keterkaitan antar konsep dan mengaplikasikan konsep atau algoritma, secara luwes, akurat, efisien, dan tepat dalam pemecahan masalah". Berdasarkan tujuan pembelajaran matematika tersebut, maka salah satu kemampuan yang harus dimiliki siswa dalam pembelajaran matematika yaitu kemampuan dalam memahami konsep matematika. Menurut Karso dkk (2011: 1.42) tujuan akhir dari belajar matematika adalah pemahaman konsep terhadap konsep-konsep matematika yang relatif abstrak.

Konsep-konsep matematika yang relatif abstrak perlu dipahami dengan menggunakan contoh-contoh konkrit yang dapat mempermudah peserta didik dalam memahami konsep matematis. Sesuai dengan yang dikemukakan oleh piaget bahwa perkembangan kognitif siswa sekolah dasar berada pada tahap operasional konkrit yang berlangsung pada umur 7,0 - 11 tahun (Taufik, 2013: 54). Guru harus menciptakan pembelajaran yang mampu melibatkan benda-benda konkrit yang dapat mengantarkan siswa pada konsep-konsep yang abstrak. Namun, pada kenyataannya penggunaan benda-benda konkrit sangat jarang dilibatkan dalam pembelajaran matematika, peserta didik justru langsung dihadapkan pada persoalan-persoalan yang abstrak sehingga siswa hanya mengetahui rumus-rumus tanpa memahami konsep yang sebenarnya.

Menurut Suherman, dkk (Azmi, 2017: 71) konsep abstrak yang baru dipahaminya itu akan mengendap, melekat, dan tahan lama bila ia belajar melalui berbuat dan pengertian, bukan hanya melalui mengingat-ingat fakta. Melalui pendekatan Concrete-Pictorial-Abstract siswa dapat belajar menggunakan benda-benda konkrit yang dapat menjadi pembelajaran lebih bermakna sehingga konsep yang dipahaminya akan melekat.

Pendekatan Concrete-Pictorial-Abstract dapat digunakan pada pembelajaran matematika sebab pada pendekatan ini Peserta didik melalui tiga tahapan pembelajaran yang dapat mempermudah Peserta didik dalam memahami konsep matematis seperti yang diungkapkan oleh Witzel (Azmi, 2017: 71) pendekatan Concete-Pictorial-Abstract tahap pembelajarannya dimulai dari tahap konkret, siswa diajak mengenal atau menemukan konsep secara langsung melalui alat peraga manipulatif dari benda konkret, dilanjutkan dengan tahap representasi bergambar dari manipulasi benda konkret dan diakhiri pada tahap ketiga yaitu menyelesaikan masalah matematika secara tidak langsung menggunakan notasi abstrak. 
Berdasarkan permasalahan di atas, penelitian ini adalah Penerapan Pendekatan Concrete-Pictorial-Abstract terhadap Kemampuan Pemahaman Konsep Matematis pada Mata Pelajaran Matematika Kelas V SD.

\section{METODE PENELITIAN}

Penelitian kali ini mengguankan metode kuasi eksperimen dengan bentuk design Pretest-Posttest Control Group Design. Dalam penelitian ini menggunakan dua kelompok yang diberikan perlakuan berbeda. Kelompok pertama adalah kelompok yang pembelajarannya menggunakan pendekatan Concrete-Pictorial-Abstract disebut kelas eksperimen, sedangkan kelompok kedua adalah kelompok yang pembelajarannya menggunakan menggunkan pendekatan Saintifik disebut kelas kontrol. Populasi yang digunakan dalam penelitian ini adalah seluruh siswa SDN Simpang Tiga yang terdaftar pada tahun ajaran 2019/2020. Teknik yang digunakan untuk pengambilan sampel pada penelitian ini ialah sampling purposive yaitu kelas $\checkmark$ yang dibagi menjadi dua kelompok belajar yaitu $V A$ sebagai kelas kontrol dan VB sebagai kelas eksperimen. Teknik pengumpulan data penelitian ini berupa tes yaitu pretest dan posttest. Instrumen yang digunakan pada penelitian adalah soal uraian kemampuan pemahaman konsep matematis berdasarkan indikator yang telah ditetapkan oleh peneliti dalam materi jaring-jaring bangun ruang.

Sebelum soal tes digunakan, soal tes terlebih dahulu diujicobakan. Uji coba tersebut dimaksudkan untuk mengetahui validitas, reliabilitas, indeks kesukaran dan daya pembeda pada tiap butir soal. Menurut Arifin (2012) validitas adalah suatu derajat ketepatan/kelayakan instrumen yang digunakan untuk mengukur apa yang akan diukur. Berikut ini adalah hasil perhitungan uji coba yang disajikan dalam tabel berikut ini.

Tabel 1. Hasil Uji Validitas Soal Uji

\begin{tabular}{cccc}
\hline Nomor soal & r-hitung & r-tabel & Keterangan \\
\hline 1 & 0,75 & 0,36 & Valid \\
\hline 2 & 0,71 & 0,36 & Valid \\
\hline 3 & 0,50 & 0,36 & Valid \\
\hline 4 & 0,48 & 0,36 & Valid \\
\hline 5 & 0,41 & 0,36 & Valid \\
\hline 6 & 0,52 & 0,36 & Valid \\
\hline 7 & 0,75 & 0,36 & Valid \\
\hline 8 & 0,74 & 0,36 & Valid \\
\hline
\end{tabular}

Berdasarkan tabel 1 dapat dilihat bahwa semua soal uji coba dinyatakan valid dan dapat digunakan.

Menurut Azwar (2011) reliabilitas adalah sejauh mana hasil dari pengukuran yang mempunyai kepercayaan, keterandalan, keajegan, konsistensi, kestabilan yang dapat dipercaya. Pengujian reliabilitas dilakukan untuk menganalisa data/instrumen penelitian berupa butir-butir soal, apakah reliabel atau tidak reliabel. Metode yang 
digunakan dalam pengujian reliabilitas data ini menggunakan Cronbach Alpha. Berdasarkan hasil perhitungan reliabilitas diperoleh $r_{11}=0,69$ maka reliabilitas soal tinggi. Daya pembeda soal adalah kemampuan suatu soal untuk membedakan antara siswa yang berkemampuan tinggi dengan siswa yang berkemampuan rendah (Arikunto, 2016). Hasil analisis daya pembeda soal uji coba terlihat pada tabel 2 berikut ini.

\begin{tabular}{ccc}
\multicolumn{3}{c}{ Tabel 2. Hasil Analisis Daya Pembeda Soal Uji Coba } \\
\hline Nomor Soal & $\begin{array}{c}\text { Daya } \\
\text { Pembeda }\end{array}$ & Keterangan \\
\hline 1 & 0,56 & Baik \\
\hline 2 & 0,63 & Baik \\
\hline 3 & 0,22 & Cukup \\
\hline 4 & 0,19 & Jelek \\
\hline 5 & 0,16 & Jelek \\
\hline 6 & 0,28 & Cukup \\
\hline 7 & 0,78 & Baik Sekali \\
\hline 8 & 0,69 & Baik \\
\hline
\end{tabular}

Berdasarkan tabel 2 dapat dilihat interpretasi masing-masing soal. Dari 8 soal uji coba tersebut, 2 soal mempunyai daya pembeda yang jelek, 2 soal mempunyai daya pembeda yang cukup, 3 soal mempunyai daya pembeda yang baik dan 1 soal mempunyai daya pembeda yang baik sekali.

Uji tingkat kesukaran dilakukan untuk mengetahui apakah instrumen termasuk ke dalam kategori mudah, sedang atau sukar. Hasil analisis tingkat kesukaran soal uji coba terlihat pada tabel 3 berikut ini.

\begin{tabular}{ccc}
\begin{tabular}{c} 
Tabel 3. Hasil Analisis Tingkat Kesukaran Soal Uji Coba \\
\hline Nomor soal
\end{tabular} & $\begin{array}{c}\text { Tingkat } \\
\text { Kesukaran }\end{array}$ & Keterangan \\
\hline 1 & 0,66 & Sedang \\
\hline 2 & 0,66 & Sedang \\
\hline 3 & 0,77 & Mudah \\
\hline 4 & 0,75 & Mudah \\
\hline 5 & 0,73 & Mudah \\
\hline 6 & 0,70 & Sedang \\
\hline 7 & 0,52 & Sedang \\
\hline 8 & 0,38 & Sedang \\
\hline
\end{tabular}

Bedasarkan tabel 3 dapat dilihat interpretasi masing-masing soal. Dari 8 soal uji coba tersebut, 3 soal termasuk ke dalam kategori mudah dan 5 soal termasuk dalam kategori sedang. Berdasarkan hasil uji coba validitas, reliabilitas, daya pembeda dan tingkat kesukaran, maka butir soal yang akan digunakan sebagai instrumen tes kemampuan pemahaman konsep matematis yaitu soal nomor 1, 2, 3, 6, 7 dan 8 
sedangkan pada soal no 4 dan 5 tidak digunakan karena memiliki daya pembeda yang jelek dan sudah terwakili oleh indikator soal nomor 3 dan 6. Data yang telah diperoleh dari hasil tes dianalisis dengan melakukan uji normalitas yaitu uji chi-kuadrat, uji homogenitas yaitu uji F dan uji kesamaan rata-rata yaitu uji $†$.

\section{HASIL DAN PEMBAHASAN}

Data hasil penelitian yang dideskipsikan adalah data pretest dan posttest tentang kemampuan pemahaman konsep matematis siswa yang diajarkan dengan menggunakan pendekatan Concrete-Pictorial-Abstract pada kelas eksperimen dan pendekatan Saintifik pada kelas kontrol. Pretest dilakukan sebelum siswa diberikan perlakuan. Hasil analisis skor pretest kemampuan pemahaman konsep matematis dapat dilihat pada tabel 4 berikut ini.

Tabel 4. Hasil Analisis Skor Pretest Kemampuan Pemahaman Konsep Matematis

\begin{tabular}{llllrrr}
\hline \multicolumn{1}{c}{ Kelas } & $\mathrm{N}$ & $X_{\max }$ & $X_{\min }$ & $\overline{\mathrm{X}}$ & $\mathrm{s}$ & $\mathrm{s}^{2}$ \\
\hline Eksperimen & 20 & 25 & 4,2 & 17,07 & 5,66 & 32,06 \\
\hline Kontrol & 20 & 25 & 8,3 & 17,55 & 4,49 & 20,16 \\
\hline
\end{tabular}

Tabel 4 menggambarkan bahwa dari 20 siswa diperoleh hasil data pretest kelas eksperimen yaitu rata-rata $(\bar{X})$ 17,07, simpangan baku $(s) 5,66$, dan varians $\left(s^{2}\right) 32,06$, dalam data ini skor kemampuan pemahaman konsep matematis berada pada rentang nilai 0-100 diperoleh nilai rendah 4,2 dan nilai tertinggi 25. Pada kelas kontrol diperoleh data pretest kelas kontrol dengan rata-rata $(\bar{X}) 17,55$, simpangan baku $(s)$ 4,49 , dan varians $\left(s^{2}\right) 20,16$, skor kemampuan pemahaman konsep matematis berada pada rentang nilai 0-100 diperoleh nilai rendah 8,3 dan nilai tertinggi 25. Posttest dilakukan setelah siswa diberikan perlakuan. Hasil analisis skor posttest kemampuan pemahaman konsep matematis dapat dilihat pada tabel 5 berikut ini.

Tabel 5. Hasil Analisis Skor Posttest Kemampuan Pemahaman Konsep Matematis

\begin{tabular}{ccccccc}
\hline Kelas & $\mathrm{N}$ & $X_{\max }$ & $X_{\min }$ & $\overline{\mathrm{X}}$ & $\mathrm{s}$ & $\mathrm{s}^{2}$ \\
\hline Eksperimen & 20 & 95,8 & 33,3 & 73,45 & 15,94 & 235,94 \\
\hline Kontrol & 20 & 95,8 & 33,3 & 61,75 & 19,73 & 389,14 \\
\hline
\end{tabular}

Tabel 5 menggambarkan bahwa dari 20 siswa diperoleh hasil data posttest kelas eksperimen yaitu rata-rata $(\bar{X}) 73,45$, simpangan baku $(s)$ 15,94, dan varians $\left(s^{2}\right)$ 235,94 . Dalam data ini skor kemampuan pemahaman konsep matematis berada pada rentang nilai 0-100 diperoleh nilai rendah 33,3 dan nilai tertinggi 95,8. Pada kelas kontrol diperoleh data posttest dengan rata-rata $(\bar{X}) 61,75$, simpangan baku $(s) 19,73$, dan varians $\left(s^{2}\right) 389,14$, skor kemampuan pemahaman konsep matematis berada pada rentang nilai 0-100 diperoleh nilai rendah 33,3 dan nilai tertinggi 95,8

Uji normalitas digunakan untuk mengetahui apakah data prestest dan posttest kelas eksperimen pertama dan kelas kontrol berdistribusi normal atau tidak. Suatu data 
membentuk distribusi normal bila jumlah data di atas dan di bawah rata-rata sama, demikian juga simpangan bakunya (Sugiyono, 2013: 81). Uji normalitas menggunkan uji chi-kuadrat $\left(x^{2}\right)$ dengan taraf nyata $a=0,05$ dan $(\mathrm{dk})=\mathrm{k}-1$. Berikut hipotesis pengujiannya:

$H_{0} \quad$ : Data berdistribusi normal

$H_{1} \quad$ : Data tidak berdistribusi normal

Hasil uji normalitas distribusi data pretest dan posttest kemampuan pemahaman konsep matematis siswa kelas eksperimen dan kontrol dapat dilihat pada tabel berikut ini.

Tabel 6. Hasil uji normalitas distribusi data pretest
kemampuan pemahaman konsep matematis
\begin{tabular}{llcl}
\hline Kelas & $x_{\text {hitung }}^{2}$ & $x_{\text {tabel }}^{2}$ & Kesimpulan \\
\hline Eksperimen & 1,68 & 11,07 & Terima $H_{0}$ \\
\hline Kontrol & 1,66 & 11,07 & Terima $H_{0}$ \\
\hline
\end{tabular}

Tabel 7. Hasil uji normalitas distribusi data posttest kemampuan pemahaman konsep matematis

\begin{tabular}{llcl}
\hline Kelas & $x_{\text {hitung }}^{2}$ & $x_{\text {tabel }}^{2}$ & Kesimpulan \\
\hline Eksperimen & 5,43 & 9,49 & Terima $H_{0}$ \\
\hline Kontrol & 6,96 & 9,49 & Terima $H_{0}$ \\
\hline
\end{tabular}

Pada tabel 6 dan 7 terlihat bahwa nilai $x_{\text {hitung }}^{2} \leq x_{\text {tabel }}^{2}$, hal ini berarti bahwa $H_{0}$ diterima, dengan demikian dapat disimpulkan bahwa kemampuan pemahaman konsep matematis siswa pada kelas eksperimen dan kelas kontrol berdistribusi normal. Setelah uji normalitas dilakukan uji homogenitas kedua varians. Pengujian ini dilakukan untuk mengetahui apakah varians-varians dari tes awal dan tes akhir dari kelas eksperimen dan kelas kontrol homogen atau tidak homogen. Kriteria pengujian yang digunakan adalah jika $F_{\text {hitung }}<F_{\text {tabel }}$ maka $H_{0}$ diterima. Hasil perhitungan uji homogenitas data pretest dan posttest kemampuan pemahaman konsep matematis dapat dilihat pada tabel 8 berikut.

\begin{tabular}{|c|c|c|c|}
\hline Data & $F_{\text {hitung }}$ & $F_{\text {tabel }}$ & Kesimpulan \\
\hline Pretest & 1,59 & 2,165 & Terima $H_{0}$ \\
\hline Posttest & 1,53 & 2,165 & Terima $H_{0}$ \\
\hline
\end{tabular}

Berdasarkan hasil perhitungan pada tabel 8 di atas. Terlihat bahwa $F_{\text {hitung }}<F_{\text {tabel }}$ maka kesimpulan yang diperoleh adalah $H_{0}$ diterima, artinya data kemampuan pemahaman konsep matematis kedua kelas, yaitu kelas eksperimen dan kelas kontrol memiliki varians yang homogen. 
Berdasarkan uji normalitas dan uji homogenitas data pretest dan posttest pada kedua kelas sampel diketahui bahwa data kemampuan pemahaman konsep matematis berdisdribusi normal dan memiliki variansi yang homogen, maka selanjutnya dilakukan uji † untuk menguji hipotesis penelitian. Kriteria pengujiannya ialah sebagai berikut:

Jika $t_{\text {hitung }} \leq t_{\text {tabel }}$, maka $H_{0}$ diterima dan $H_{a}$ ditolak

Jika $t_{\text {hitung }}>t_{\text {tabel }}$, maka $H_{0}$ ditolak dan $H_{a}$ diterima

Hipotesis yang diuji adalah:

$H_{0}$ : Kemampuan pemahaman konsep matematis yang menggunak pendekatan concrete-pictorial-abstract kurang baik daripada pendekatan Saintifik pada mata pelajaran Matematika kelas $\vee$ di SDN Simpang Tiga.

$H_{a}$ : Kemampuan pemahaman konsep matematis yang menggunakan pendekatan concrete-pictorial-abstract lebih baik daripada pendekatan Saintifik pada mata pelajaran Matematika kelas $V$ di SDN Simpang Tiga.

Hasil uji kesamaan rata-rata data pretest dan posttest kemampuan pemahaman konsep matematis dapat dilihat pada tabel berikut ini.

Tabel 9. Hasil Uji Kesamaan Rata-rata Data Pretest Dan Posttest
Kemampuan Pemahaman Konsep Matematis
\begin{tabular}{lccc}
\hline Data & $t_{\text {hitung }}$ & $t_{\text {tabel }}$ & Kesimpulan \\
\hline Pretest & $-0,296$ & 2,02 & Terima $H_{0}$ \\
\hline Posttest & 2,063 & 2,02 & Tolak $H_{0}$ \\
\hline
\end{tabular}

Berdasarkan hasil perhitungan pada tabel 9 di atas, nilai pretest menunjukkan bahwa $t_{\text {hitung }} \leq t_{\text {tabel }}$ sehingga $H_{0}$ diterima, yang artinya Kemampuan pemahaman konsep matematis yang menggunakan pendekatan concrete-pictorial-abstract kurang baik daripada pendekatan Saintifik pada mata pelajaran Matematika kelas $V$ di SDN Simpang Tiga.

Pada nilai pottest menunjukkan bahwa $t_{\text {hitung }}>t_{\text {tabel }}$ sehingga $H_{0}$ ditolak, yang artinya Kemampuan pemahaman konsep matematis yang menggunakan pendekatan concrete-pictorial-abstract lebih baik daripada pendekatan Saintifik pada mata pelajaran Matematika kelas $V$ di SDN Simpang Tiga. Pembelajaran yang dilakukan pada kelas eksperimen yaitu dengan diberi perlakuan dengan menerapkan pendekatan Concrete-Pictorial-Abstract selama 6 kali pertemuan pada materi jaring-jaring bangun ruang. Pada pertemuan pertama dan kedua materinya yaitu mengenai sifat-sifat bangun ruang balok dan kubus, peserta didik berdiskusi secara berkelompok mengerjakan LKPD yang memiliki 3 bagian. Pertama, pendidik mengeluarkan benda-benda yang berbentuk balok yaitu tempat pensil dan karduskardus kecil untuk di amati oleh pesera didik dan dilanjutkan dengan melakukan tanya jawab, kemudian peserta didik mengerjakan LKPD bagian 1 yang melibatkan benda-benda konkret yaitu dengan melakukan pengamatan benda-benda apa 
saja yang berbentuk balok dan kubus yang terdapat dilingkungan sekitar selama 10 menit dan menuliskan hasilnya pada LKPD bagian 1, setelah itu perwakilan kelompok menyampaikan hasilnya di depan kelas dan dibahas secara bersama-sama. Kemudian dilanjutkan mengerjakan LKPD bagian 2, setiap kelompok mengeluarkan alat gambar untuk menggambarkan sketsa salah satu benda balok dan kubus yang telah dituliskan pada LKPD bagian 1 dan diberi abjad pada setiap sudutnya, kemudian perwakilan kelompok memperlihatkan hasilnya di depan kelas. Setelah itu, peserta didik mengerjakan LKPD bagian 3 yaitu dengan menentukan dan menghitung banyaknya titik duduk, rusuk dan sisi bangun ruang balok dan kubus yang telah digambar pada LKPD bagian 2 pada tabel yang telah disediakan.

Pada pertemuan ketiga dan keempat materinya yaitu mengenai jaring-jaring balok dan kubus, peserta didik berdiskusi secara berkelompok mengerjakan LKPD yang memiliki 3 bagian. Pertama, pendidik mengeluarkan kardus kemasan yang berbentuk balok dan kubus seperti kardus kemasan sabun dan parfum untuk diperlihkan kepada peserta didik bentuk dari jaring-jaring balok benda-benda yang berbentuk balok dan kubus, kemudian peserta didik mengerjakan LKPD bagian 1 dengan menuliskan berbagai hal-hal dalam keseharian terkait benda konkret yang memiliki keterkaitan dengan jaring-jaring bangun ruang balok dan kubus dan menuliskan alasan mengapa hal tersebut memiliki keterkaitan dengan bangun ruang balok, setelah itu perwakilan kelompok menyampaikan hasilnya di depan kelas dan dibahas secara bersama-sama. Kemudian setiap kelompok mengeluarkan alat-alat untuk membuat jaring-jaring balok dan kubus pada karton sesuai dengan bentuk kardus kemasan yang telah dibongkar dan menggambarkan kembali bentuk jaring-jaring tersebut pada LKPD bagian 2, kemudian perwakilan kelompok memperlihatkan hasilnya di depan kelas. Setelah itu, peserta didik mengerjakan LKPD bagian 3 yaitu dengan menganalisis bagian jaring-jaring yang sudah diberi tanda khusus secara abstrak akan saling berhadapan antar sisi lainnya yaitu dengan menebak bagian atas pada jaring-jaring balok dan kubus.

Pada pertemuan kelima dan keenam materinya yaitu mengenai luas permukaan kubus dan balok, peserta didik berdiskusi secara berkelompok mengerjakan LKPD yang memiliki 3 bagian. Pertama, setiap kelompok mengeluarkan kembali jaringjaring kubus dan balok yang telah dibuat pada pertemuan sebelumnya, kemudian peserta didik berdiskusi menjawab pertanyaan pada LKPD bagian 1 untuk menentukan luas bangun datar penyusunnya dan menentukan luas jaring-jaring tersebut dengan mengamati jaring-jaring yang telah dibuat, kemudian perwakilan kelompok menyampaikan hasilnya di depan kelas dan dibahas secara bersamasama. Selanjutnya setiap kelompok mengerjakan LKPD bagian 2 yaitu menggambar jaring-jaring kubus kembali namun dengan panjang rusuk yang telah ditentukan dan perwakilan kelompok memperlihatkan hasilnya di depan kelas. Setelah itu, setiap kelompok kembali berdiskUsi untuk menjawab pertanyaan pada LKPD bagian 3 yaitu menghitung luas jaring-jaring sesuaidengan gambar pada LKPD bagian 2, kemudian perwakilan kelompok menyampaikan hasilnya dan dibahas secara bersama-sama. 
Data hasil analisis skor pretest menunjukkan bahwa rata-rata nilai kelas kontrol lebih tinggi daripada nilai kelas eksperimen, namun hasil analisis skor posttest menunjukkan bahwa nilai rata-rata kelas eksperimen lebih tinggi daripada kelas kontrol, hal tersebut dikarenakan pada kelas eksperimen diberi perlakuan dengan menerapkan pendekatan Concrete-Pictorial-Abstract, dimana peserta didik belajar memahami konsep tidak langsung secara abstrak melainkan dengan proses dari yang konkret menuju semi konkret dan barulah berpikir secara abstrak sehingga proses yang telah dilalui tersebut dapat membantu siswa dalam memahami konsep matematika dan bukan hanya mengingat-ingat rumus saja.

Tahapan pembelajaran yang telah dilakukan dengan menggunakan pendekatan Concrete-Pictorial-Abstract sesuai dengan pendapat Witzel (Ikram, Rahma, Fadliyah, 2017: 655) pendekatan Concrete-Pictoral-Abstract terdiri dari tiga tahapan, yaitu: (1) manipulasi benda-benda konkret (concrete), (2) Representasi pictorial dari manipulasi konkret, (3) Memecahkan menggunakan notasi abstrak. Lebih jelas lagi diungkapkan oleh Munawaroh \& Priatna (2017: 59) Pendekatan Concrete-PictorialAbstract dimulai dari belajar secara visual, secara langsung, meraba, serta melibatkan aspek kinestetik siswa untuk membangun pemahaman siswa, setelah itu siswa memperluas pemahaman matematika melalui representasi dari benda-benda konkret tersebut yang direpresentasikan melalui gambar, diagram atau bentuk lainnya. Setelah kedua proses tersebut selesai, barulah siswa naik ke tingkat pemahaman yang lebih tinggi, yakni memahami konsep secara abstrak. Penerapan pendekatan Concrete-Pictorial-Abstract lebih menekankan pada kemampuan pemahaman konsep matematis siswa. Menurut Kilpatrik et al (Lestari dan Yudhanegara, 2015: 81) pemahaman konsep merupakan kemampuan yang berkenaan dengan memahami ide-ide matematika yang menyeluruh dan fungsional.

\section{KESIMPULAN DAN SARAN}

Berdasarkan hasil penelitian dapat disimpulkan bahwa Kemampuan pemahaman konsep matematis yang menggunakan pendekatan Concrete-Pictorial-Abstract lebih baik daripada pendekatan Saintifik pada mata pelajaran Matematika kelas $\mathrm{V}$ di SDN Simpang Tiga. Peneliti merekomendasikan pengelolaan waktu yang tepat pada setiap tahap pembelajaran khususnya pembelajaran menggunkan pendekatan Concrete-Pictorial-Abstract

\section{UCAPAN TERIMAKASIH}

Terimakasih kepada lbu Indhira Asih V. Y, S.Si., M. Pd selaku dosen pembimbing 1 dan Bapak Trian Pamungkas Alamsyah, M. Pd selaku dosen pembimbing 2 yang telah memberikan masukan dan arahan dalam penyusunan hasil penelitian ini. 


\section{DAFTAR PUSTAKA}

Amir, A. (2014). Pembelajaran Matematika SD dengan Menggunakan Media Manipulatif. Forum Pendagogik . VI(01): 72-89.

Anitah, S. (2014). Strategi Pembelajaran di SD. Jakarta: Universitas Terbuka.

Arifin, Z. (2012). Penelitian Pendidikan Metode dan Paradigma. Bandung: Remaja Rosda Karya.

Arikunto, S. (2016). Prosedur Penelitian: Suatu Pendekatan Praktik. Jakarta: Rineka Cipta.

Azmi, M. P. (2017). Penerapan Pendekatan Concrete-RepresentationalAbstract.Abstract (CRA) Berbasis Intuisi untuk Meningkatkan Kemampuan Komunikasi Matematika Siswa SMP. Jurnal Pendidikan Matematika FKIP Univ. Muhammadiyah Metro . 6(1): 68-80.

Azwar, S. (2011). Reliabilitas dan Validitas. Yogyakarta: Pustaka Pelajar.

Ikram, Z. J. W, Nasir, R., \& Fadliyah, R. (2017). Pendekatan Concrete Pictorial Abstract (CPA) Untuk Memfasilitasi Pemahaman Konsep Siswa. https://www.researchgate.net/publication/324262524_PENDEKATAN_CON CRETE_PICTORIAL_ABSTRACT_CPA_UNTUK_MEMFASILITASI_PEMAHAMAN_KO NSEP_SISWA. diakses pada tanggal 02/09/2019.

Karso, d. (201 1). Pendidikan Matematika 1. Jakarta: Universitas Terbuka.

Lestari, \& Yudhanegara. (2015). Penelitian Pendidikan Matematika. Bandung: Refika Aditama.

Munawaroh, A. R., \& Priatna, D. (2017). Pengaruh Pendekatan Concrete Representational Abstract (CRA) Terhadap Peningkatan Kemampuan Koneksi Matematis Siswa. Antologi UPI . 5(1): 56-67.

Novitasari, D. (2016). Pengaruh Penggunaan Multimedia Interaktif Terhadap Kemampuan Pemahaman Konsep Matematis Siswa. Jurnal Pendidikan Matematika \& Matematika. Jurnal Pendidikan Matematika \& Matematika, 2(2): 8-18.

Sugiyono. (2015). Metode Penelitian Kuantitatif, Kualitatif dan R\&D. Bandung: Alfabeta.

Taufik, M. (2013). Pengantar Pendidikan. Tangerang: CV. Mujahid Press

Wulandari, Y., \& Sutriyono, S. (2018). Deskripsi Pemahaman Konsep Bangun Datar oleh Siswa Kelas VIII SMP Negeri 03 Salatiga Berkemampuan Rendah. MAJU: Jurnal Ilmiah Pendidikan Matematika, 5(2).

Yuliyanto, A., \& Putri, H. E. (2019). Peningkatan Hasil Belajar Siswa SD Melalui Pendekatan Concrete-Pictorial-Abstract. Metodik Didaktik . 14(2): 75-85. 